\title{
PREDATION AT BANK SWALLOV COLONIES NEAR KATEPWA LAKE
}

DALE G.HJERTAAS and PAULE HJERTAAS, 15 Olson Place, Regina, Saskatchev S4S 2J6

During 1980 and 1981, we studied Bank Swallow colonies along the Qu'Appelle Valley in the area of Katepwa Lake for the senior author's M. Sc. research. ${ }^{4}$ Several cases of predation observed at these Bank Swallow colonies are reported here.

We made repeat observations at 498 nests and recorded 183 known nest failures during 1980 and 1981. Only 9 of these failures were directly attributable to predation. Additional cases of predation were recorded in 1982 in the same area.

The most exciting predator-prey interaction observed was on 13 July 1980, at approximately 6:30 p.m. While driving through Lebret Dale glanced at a $\mathrm{B}$ Swallow colony at the edge of town saw a Bank Swallow fluttering in fror its hole, his impression was that it struggling as though caught with a st around its foot. Thinking the bird have become entangled in an unust long piece of nesting material, we tur the car around at the next intersed and drove back to the colony. At firs saw nothing and almost concluded bird was gone when we noticed a gd snake holding a struggling Bank Swa at the bank base.

The snake was in and around s Russian Thistle on the talus slope be the nest holes. It held the swallow

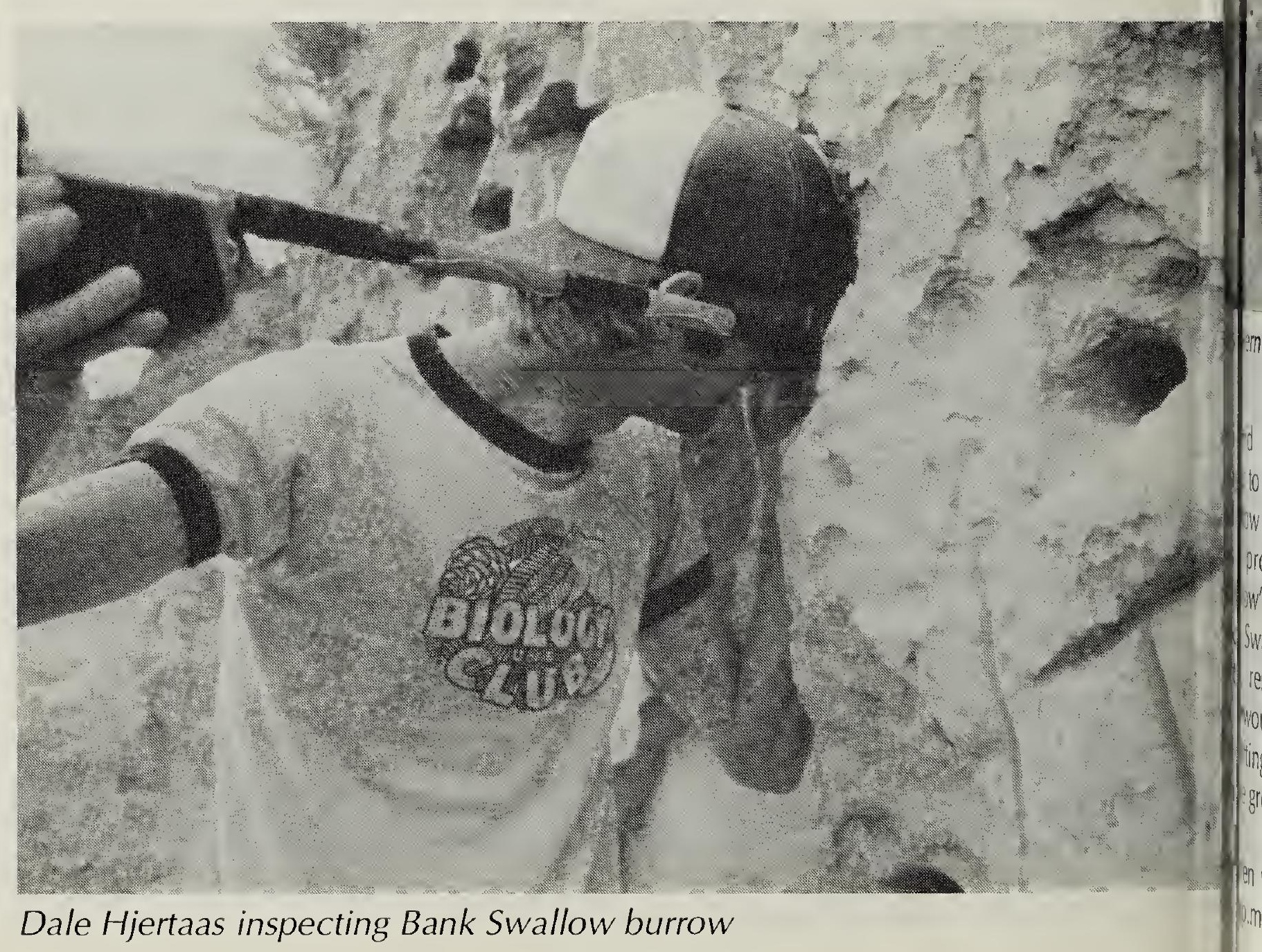




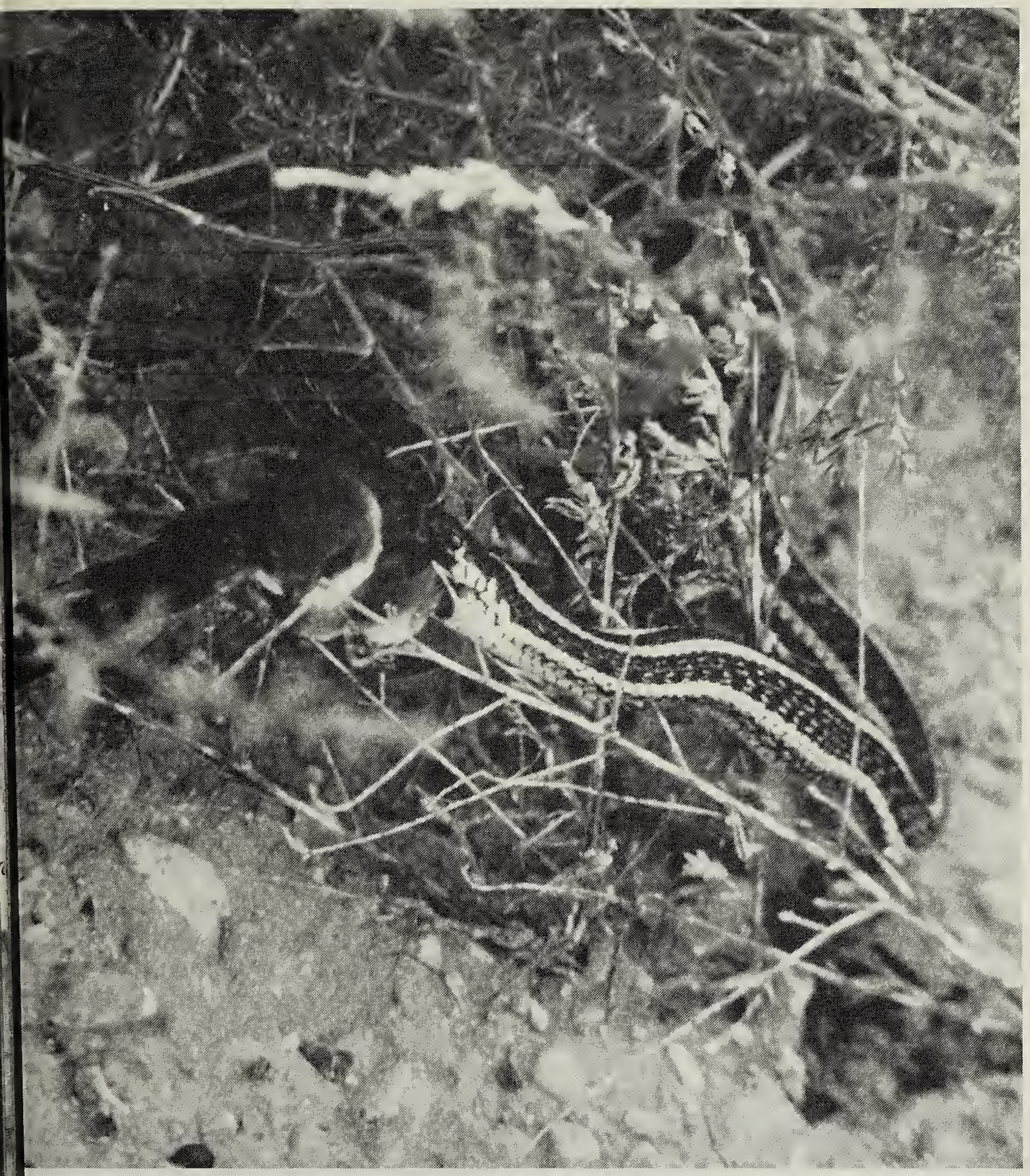

\section{tern Plains Garter Snake with Bank Swallow}

in the wing and appeared to be s to slowly shift its grip until it could ow the bird from the front or back. process was hampered by the ow's struggles and by the wings. The Swallow, which appeared to be an rested quietly some of the time, would struggle, flapping its wings fting the snake's head several inches e ground.

en we returned between 8:00 and p.m. they were at the same place.
The snake had shifted its grip and was trying to swallow the bird tail first, having engulfed it up to the wings.

This case of predation did not cause a nest failure as young were already flying from all nests at the colony, although a few Bank Swallows were still returning to nest tunnels.

The ten nest holes at this colony were from 1.3 to $1.75 \mathrm{~m}$ above the talus slope and between 0.75 and $1.5 \mathrm{~m}$ from the 
bank top. We did not attempt to estimate the length of the Western Plains Garter Snake, but believe it was able to reach nest holes from the bank top. We do not know whether it trapped a swallow which was already inside the tunnel, or waited in ambush for a returning swallow. When we drove by, the snake must have just caught the swallow and was struggling with it in the tunnel entrance. Freer observed a Black Snake enter a burrow from the top of the bank and visit three tunnels before taking a young swallow. ${ }^{2}$ Black Rat Snakes have also been noted as predators at Bank Swallow colonies. ${ }^{16}$ Mobbing by the Bank Swallows was an ineffectual defence against these snakes. ${ }^{2}$ Steepness of the bank and an overhang at the bank top may prevent snakes from reaching the burrows.'

In 1981 a Deer Mouse nested in an old swallow tunnel in a gravel stock pile south of Lebret. Small ledges on the gravel face allowed the mouse to travel back and forth along the bank face and reach other swallow holes. The mouse appeared to eat the swallows' eggs as we observed bits of broken egg shells in failed swallow nests. Nine of the 16 nests at this colony failed due to the mouse eating eggs. Four other nests failed for reasons which remain unknown because we could not see into the nest chamber. The Deer Mouse may have been involved in these nest failures as well. The only nest of 16 which fledged young at this colony was the farthest nest from the hole occupied by the deer mouse.

Stoner reported a Deer Mouse in a Bank Swallow colony but could see no evidence of the mouse having damaged eggs or young. 'These mice have been reported as a major predator of Spotted Sandpiper eggs. ${ }^{5}$

Bank Swallows have been reported to mob mammalian predators such as chipmunks which sometimes prey on nestlings or eggs. ${ }^{3}$ We never observed the
Bank Swallows along the Qu'App valley use such mobbing tactics. On June 1980 we watched both a Least Cl munk and a Thirteen-lined Ground Sq. rel at a colony. Both moved on the ta slope and on ledges on the actual bank without any interference by swallows. The chipmunk actually loo into some of the burrows. Although Bank Swallows took no action, a Ho Wren which was nesting in an ur cupied Bank Swallow tunnel attac and chased the chipmunk from the $b$ face.

During 1980 and 1981 we observec evidence of predation by large mamr which we had thought would be a $m$ factor influencing where Bank Swall nested. However in 1982, 28 of $30 \mathrm{r}$ at one gravel pit complex and 1 of 8 second pit, approximately $2 \mathrm{~km}$ at were dug out by a mammal which cavated down to the nest chamber $f$ above. Perhaps it could hear or smel nestlings or adults as holes were cavated directly to the chamber and contents scooped out through a s opening. Bits of egg shell at some $r$ suggested they were still at egg st while others clearly contained yc when preyed upon between 11 anc July.

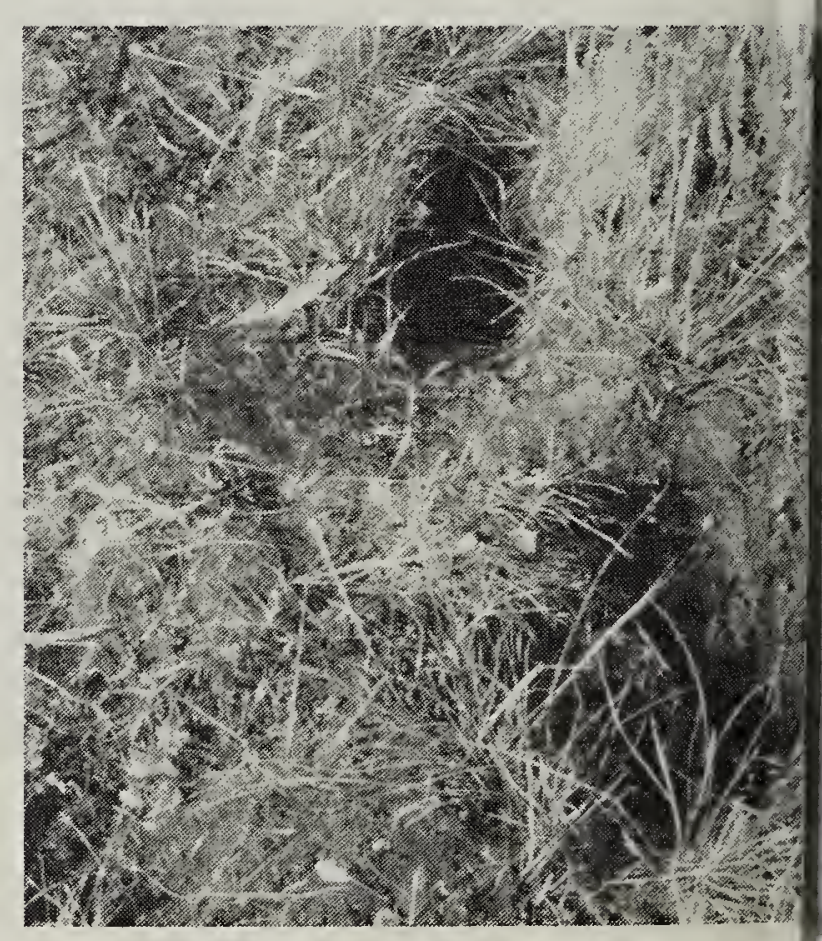

Holes dug by mammalian predators 
The species of predator could not be intified with certainty as recent rains d eliminated tracks before each of our its. However, size of the holes (they re 15 to $18 \mathrm{~cm}$ wide at the top, and nel shaped with only a small opening the nest chamber), and some scats ggested a larger mammal such as a ink, fox or badger was the predator. ner reported a Striped Skunk digging wn to as many as five nests over a hight period. ${ }^{7}$ Nests lower than $60 \mathrm{~cm}$ re usually safe from this skunk. Freer ferved a colony of 30 nests entirely troyed by a mammal digging down $n$ above.

terestingly, at the colony where only nest was excavated, it was the one sest to the surface. Tunnel entrances of ts preyed on by this mammal ranged n 11 to $42 \mathrm{~cm}$ below the bank top. The lance from the ground surface to the t chamber was not recorded.

redation at Bank Swallow colonies in Qu'Appelle Valley was a minor rce of nest failure in 1980 and 1981 . wever, as shown by the almost total ure of one colony in 1982, predation have a significant impact in some es and is undoubtedly a strong selec- tive force in determining the types of banks selected by Bank Swallows.

1 BLEM, C.R. 1979. Predation of Black Rat Snakes on a Bank Swallow colony. Wilson Bull. 91:135-37.

2 FREER, V.M. 1977. Colon structure and function in the Bank Swallow Riparia riparia L. Ph. D. dissertation, State Univ. New York, Binghampton, N.Y.

3 GINEVAN, M.E. 1971. Chipmunk predation on Bank Swallows. Wilson Bull. 83:102.

4 HJERTAAS, D.G. 1984. Colony site selection in Bank Swallows. M. Sc. Thesis, Univ. of Sask., Saskatoon, Sask.

5 ORING, L.W., D.B. LANK and S.J. MAXSON. 1983. Population studies of the polyandrous Spotted Sandpiper. Auk 100:272-285.

6 PLUMMER, M.V. 1977. Predation by Black Rat Snakes in Bank Swallow colonies. Southwest Naturalist 22:147148.

7 STONER, D. 1936. Studies on the Bank Swallow Riparia riparia (Linnaeus) in the Oneida Lake Region. Roosevelt Wildl. Annals 4:127-233. 